\title{
Body image distortion and dissatisfaction in incarcerated women
}

\section{Distorção e insatisfação com a imagem corporal em mulheres privadas de liberdade}

\author{
Ana Paula Dias Inocêncio BARBOSA1 (iD) 0000-0001-7816-1398 \\ Clélia de Oliveira LYRA ${ }^{1}$ (iD) 0000-0002-1474-3812

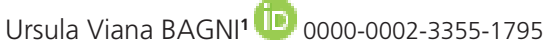

A B S T R A C T

\section{Objective}

To investigate the prevalence of Body Image distortion and dissatisfaction and evaluate the associated factors in incarcerated women in a closed regime.

\section{Methods}

Cross-sectional observational study, conducted with female inmates $(n=107)$ in Rio Grande do Norte, Brazil. Personal sociodemographic data were collected through an interview, and the height and weight were measured to obtain the body mass index. Body image was assessed using a scale of silhouettes figures for Brazilian adults. Prevalence Ratios with their respective 95\% Confidence Intervals and Bland-Altman method were used in the statistical analysis.

\section{Results}

A total of $83.3 \%$ of the participants were affected by body image distortion and $91.6 \%$ by body image dissatisfaction. More than a half (58.9\%) wanted a lower Body Mass Index $\left(9.01 \pm 5.25 \mathrm{Kg} / \mathrm{m}^{2}\right)$, however, $32.7 \%$ wanted to increase the body size $\left(6.43 \pm 4.34 \mathrm{Kg} / \mathrm{m}^{2}\right)$. The sociodemographic characteristics, nutritional status $(P R=0.99 ; 95 \% \mathrm{Cl}: 0.89-1.11)$, and the time of imprisonment $(\mathrm{PR}=1.06 ; 95 \% \mathrm{Cl}: 0.94-1.19)$ were not associated with Body Image dissatisfaction. No associations were observed between body image distortion and the time of imprisonment ( $\mathrm{PR}=1.17 ; 95 \% \mathrm{Cl}: 0.96-1.42)$ or nutritional status ( $\mathrm{PR}=1.10 ; 95 \% \mathrm{Cl}: 0.89-1.36)$.

\footnotetext{
1 Universidade Federal do Rio Grande do Norte, Centro de Ciências da Saúde, Programa de Pós-Graduação em Nutrição. Av. Senador Salgado Filho, 3000, Lagoa Nova, 59078-970, Natal, RN, Brasil. Correspondence to: UV BAGNI. E-mail: <ursulaviana@gmail.com>.

Support: This study was financed in part by the Coordenação de Aperfeiçoamento de Pessoal de Nivel Superior (Finance Code 001).

Article based on the dissertation by APDI BARBOSA, entitled "Imagem corporal em mulheres privadas de liberdade". Universidade Federal do Rio Grande do Norte; 2018.

How to cite this article

Barbosa APDI, Lyra CO, Bagni UV. Body image distortion and dissatisfaction in incarcerated women. Rev Nutr. 2019;32:e190022. http://dx.doi.org/10.1590/1678-9865201932e190022
} 


\section{Conclusion}

Most female inmates were dissatisfied with their bodies and distort their body image, indicating the need for these aspects to be included in the health promotion actions in the prison system.

Keywords: Body image. Nutritional status. Prisons. Women's health.

\section{RE S U M O}

\section{Objetivo}

Estimar a prevalência da distorção e da insatisfação com a Imagem Corporal e identificar seus fatores associados numa população de mulheres encarceradas em regime fechado.

\section{Métodos}

Estudo observacional transversal realizado com mulheres reclusas $(n=107)$ do Rio Grande do Norte, Brasil. Foram coletadas informações pessoais sociodemográficas por meio de entrevista, e mensurados o peso e a estatura para obtenção do Índice de Massa Corporal. A avaliação da imagem corporal ocorreu por meio da escala de figuras de silhuetas para adultos brasileiros. Razão de Prevalência com seus respectivos intervalos de confiança de $95 \%$ e método Bland-Altman foram empregados nas análises estatísticas.

\section{Resultados}

A distorção da imagem corporal afetou $83,3 \%$ das participantes e a insatisfação com a imagem corporal, $91,6 \%$. Mais da metade $(58,9 \%)$ desejava um índice de massa corporal menor $\left(9,01 \pm 5,25 \mathrm{Kg} / \mathrm{m}^{2}\right)$, entretanto, $32,7 \%$ queria aumentar o tamanho corporal $\left(6,43 \pm 4,34 \mathrm{Kg} / \mathrm{m}^{2}\right)$. As características sociodemográficas, o estado nutricional $(R P=0,99$ IC95\%:0,89-1,11) e o tempo de reclusão ( $R P=1,06$ IC95\%:0,94-1,19) não estiveram associados à insatisfação com a imagem corporal. Não foram verificadas associações entre a distorção da imagem corporal e o tempo de encarceramento ( $R P=1,17$ IC95\%:0,96-1,42) ou estado nutricional $(R P=1,10$ IC95\%:0,89-1,36).

\section{Conclusão}

A maioria das mulheres em reclusão é insatisfeita com seus corpos e distorce sua imagem corporal, apontando para a necessidade de incluir esses aspectos nas ações de promoção da saúde no sistema prisional.

Palavras-chave: Imagem corporal. Estado nutricional. Prisões. Saúde da mulher.

\section{NTROD U CTION}

Body Image $(\mathrm{BI})$ is a multidimensional construct that involves mental representations of the body, including size, shape, feelings, cognition and behavior [1], and researchers keep seeking to understand what BI represents and the magnitude of its effects on the behavior of individuals [2].

The BI perception can be affected by both intrinsic factors and environmental factors, especially in women $[3,4]$, in which the desire to meet standards can trigger health problems, such as depressive states, self-image and self-esteem disorders, anxiety and abusive use of licit drugs [1].

The construction of subjectivity as to what is a desirable body begins in childhood and is consolidated throughout life, i.e., Bl is developed and regenerates, being constantly renewed [1,5]. In incarcerated women, in addition to these factors, there are those imposed by the prison environment, which may potentiate or even influence in a different way the perception of their BI [6].

Imprisonment causes suffering, which is intensified by the degrading conditions of detention, overcrowding and the precarious installations [7]. It is important, therefore, to consider the "life that comes to pass within the walls of the system", seeking to understand the cultural references that circulate in this space, how the subjects signify things that occur there, and the rules which interfere with values and behaviors of confined individuals [8]. According to Verdi et al. [8], imprisoned 
individuals live in another social context with numerous special features and difficulties, which may facilitate the establishment of their own standards and references about a "normal" "adequate" and even "desirable" body within the prison.

The dissatisfaction and distortion of $\mathrm{BI}$ in a prison environment may foster the development of Chronic Non-Communicable Diseases (CNCD), in particular, obesity, and trigger inappropriate practices of weight control, depression, isolation, abandonment of self-care, low self-esteem, eating and psychological disorders. In the context of the prison system, controlling these health problems is critical, since health care is precarious such that inmates have difficult access of to healthcare professionals in everyday life [9-11].

Studies on $\mathrm{BI}$ in the prison environment are scarce $[6,12,13]$, thus, the objective of this work was to estimate the prevalence of BI Distortion (BIDist) and BI Dissatisfaction (BIDiss), and identify the factors associated in the population of women imprisoned in a closed regime.

\section{METHOD S}

This was a cross-sectional, census-type study carried out with the female inmates, who were sentenced to a closed system in Natal, Rio Grande do Norte, Brazil. The prison unit investigated is one of three existing in the state of Rio Grande do Norte that have female pavilions for prisoners already sentenced in closed regime (located in the cities of Natal, Caicó and Mossoró), and contains one of the largest concentration of female inmates with this sentence.

Although the population base was the same assessed by Andrade et al. [6], most of the participants were different, since in the prison itinerary it is very common that the closed regime evolves to semi-open, open or freedom, as well as the occurrence of exchange between prisons and the arrival of new detainees.

Pregnant, lactating, physically handicapped women or women with a disease that hindered anthropometric evaluation were considered ineligible. Women in isolation, or no longer belonging to the Prison Unit during the data collection period were excluded.

The data was collected from January to April 2015, on days and times established by the direction of the prison complex. Measurements of body weight were taken using a digital scale with precision of $100 \mathrm{~g}$ (InBody ${ }^{\circledR}$ Model R20, Seul, Coreia) and stature using a portable stadiometer with precision of $0.1 \mathrm{~cm}$ (Alturexata ${ }^{\circledR}$, Minas Gerais, Brazil), in order to assess the Body Mass Index (BMI), categorizing the nutritional status as recommended internationally by the World Health Organization. For the collection of anthropometric data, the inmates were taken in small groups by the prison staff from the cells to a small auditorium of the prison unit.

Interviews were conducted by the researchers using a questionnaire with open and closed questions, addressing socioeconomic, demographic and nutritional aspects. For security reasons, all the interviews were held with the inmates inside the cells. To favor privacy and minimize the interference of other inmates, the researchers positioned themselves next to the outside door rails and interviewed them individually in low voice.

The BI was evaluated through the Scale of Silhouette Figures (SSF) created and validated for Brazilians by Kakeshita [14] and considered reliable and valid for a clinical and epidemiological application $[2,14]$. The prison director requested that there be minimal manipulation of papers and 
pens by detainees during the study. Thus, the figures were printed on the questionnaire used in the interview, which was kept by the researcher, in a single document.

Inmates were asked to identify which figure reflected their body before imprisonment, which resembled their current body at the moment of the interview and which body figure they would like to have. The presence of BIDist was determined when the current BMI measured by Anthropometry (BMI-A) was not compatible with the current BMI Estimated by the SSF (BMI-E), i.e., when it was out of the BMI range of the selected as similar to their present body, defined by Kakeshita [14]. The level BIDist (in $\mathrm{kg} / \mathrm{m}^{2}$ ) was calculated by the difference between BMI-E and BMI-A, with positive values indicating an overestimation and negative values an underestimation of the BMI.

BIDiss was defined when the figure indicated to represent the body desired differed from that pointed out as similar to the current body at the moment of the interview. The degree of BIDiss was measured by the difference between the Desired body BMI (BMI-D) and the current body (Dissatisfaction=BMI-D-BMI-E), with positive values indicating the desire to gain weight and negative values the desire to lose weight. Values equal to zero were indicative of body image satisfaction.

The outcome variables (BIDist and BIDiss) were treated as both categorical (present or absent) and continuous variables (BMI units). Exposure variables were age ( $<30$ years; $30-49$ years; $\geq 50$ years), schooling (read and write/elementary education; secondary/higher education; and post-graduation), monthly per capita family income (<1/4 minimum wage; 1/4-1/2 minimum wages; $\geq 1 / 2$ minimum wages), marital status (single/separated/widowed; married/living with a partner), time of imprisonment $(<12$ months; 12-24 months; >24 months), the frequency of visits (weekly, fortnightly, monthly, sporadic, not receiving), having children (yes/no), and the nutritional status (eutrophic: BMI between 18.5 to 24.9Kg/m²; Excess weight: BMl from $25 \mathrm{Kg} / \mathrm{m}^{2}$ ).

The limited time available for data collection or the refusal to answer questions in the interview resulted in loss of information for some of the variables investigated. The number of individuals with missing data was higher for the variables family income per capita $(n=63)$ and education $(n=35)$, followed by time of imprisonment $(n=16)$, anthropometry $(n=15)$, frequency of visits $(n=12)$, have children $(n=1)$ and age $(n=1)$.

Individuals with such information losses were not excluded from the study as this would reduce the number of participants by more than half. It was also decided not to perform data imputation in order to avoid information bias, considering the small number of study participants remaining for some of the variables. In addition, these losses occurred randomly and in a relatively small proportion for the dependent variables $(0.0 \%$ for satisfaction with $\mathrm{BI}$ and $16.0 \%$ for distortion of $\mathrm{BI})$, thus not violating the principle of internal validity of the study. Specifically, for the variable family income per capita (58.9\% of missing data), it was presented only to describe the population investigated and evidence the low social conditions of women, as well as to show the reader the difficulty of obtaining this type of data vulnerable populations such as this. However, since information loss exceeded $50.0 \%$, it was not included in the analysis of the Prevalence Ratio (PR).

Initially, an exploratory analysis of the outcome and exposure variables was performed, and presented the frequencies and $95 \%$ Confidence Intervals $(\mathrm{Cl})$ for the categorical variables, and the means and respective dispersion measures for the continuous variables. The Wilcoxon test was used to compare the medians of the different BMI.

The agreement between the BMI-A and BMI-E values was analyzed using the Bland-Altman method. This type of analysis requires a normal distribution of the variable "Difference (Current BMI-E-BMI-A)", which was not the case. Thus, the Box-Cox analysis was conducted for this procedure. 
In addition, the Linear Regression line with its $95 \% \mathrm{Cl}$ was added to the Bland-Altman graph to show if there was a positive or negative trend regarding the BMI-E and the BMI-A.

The PR, with the respective $95 \% \mathrm{Cl}$, were used to measure the strength of the association between the dependent and independent variables. All analyses were performed using the Statistical Package for the Social Sciences, version 20.0 (SPSS Inc., Chicago, Illinois, United States), considering $p<0.05$ as statistically significant.

This study was approved by the Research Ethics Committee of the School of Health Sciences of Trairi, of the Universidade Federal do Rio Grande do Norte (UFRN, Federal University of Rio Grande do Norte), opinion No.928.144; CAAE: 38714714.0.0000.5568; and followed the recommendations of Resolution 466/2012 of the National Health Council, having participated only women who signed the Informed Consent Form.

\section{RES U L T S}

Of the 115 inmates in the prison complex in the data collection period, 1 was pregnant, 3 refused to participate in the study and 4 were released, totaling $6.1 \%$ of losses of eligible candidates.

The 107 participants were aged between 18 and 57 years (31.7 \pm 8.48 years), and most of them could read and write or had studied until elementary school (65.3\%), had a per capita family income lower than $1 / 4$ minimum salary $(68.2 \%)$ and were imprisoned for less than 2 years $(73.6 \%)$ (Table 1).

In general, participants realized that from their pre-imprisonment time to the time of data collection, their body size increased, since the median BMI-E was higher than that of the BMI Prior to imprisonment, estimated by the SSF (BMI-P). In addition, a large part also considered having a larger body than they had and what they wished to have (Figure 1).

The average BMI in the anthropometric assessment was $27.67 \mathrm{Kg} / \mathrm{m}^{2}$ and approximately $65.0 \%$ of the participants were above weight. The average BMI-E was $30.63 \mathrm{Kg} / \mathrm{m}^{2}$, and $83.3 \%$ of the participants exhibited a BIDist (Table 1). Of these, $82.7 \%$ overestimated their body size, attributing on average $5.59( \pm 2.73)$ extra BMI units on their real body BMI.

The Bland-Altman graph revealed a trend between estimated and measured BMI in the population studied, since a higher average between the BMI-E and BMI-A indicates a greater difference between the two methods. Therefore, the higher the average, the greater the BIDist, as shown by the linear regression and statistical significance (Figure 2). The BMI-E values may be $7.52 \mathrm{Kg} / \mathrm{m}^{2}$ below or $13.68 \mathrm{Kg} / \mathrm{m}^{2}$ above those obtained by BMI-A. The mean difference (bias) between BMI-E and BMI-A was $3.08 \mathrm{Kg} / \mathrm{m}^{2}$, being statistically significant.

The prevalence of women with BIDist did not differ regarding sociodemographic characteristics, the time of imprisonment ( $P R=1.17 ; 95 \% \mathrm{Cl}: 0.96-1.42)$, nutritional status ( $\mathrm{PR}=1.10 ; 95 \% \mathrm{Cl}: 0.89-1.36)$, nor with the presence of BIDiss ( $P R=1.00 ; 95 \% \mathrm{Cl}: 0.86-1.11)$ (Table 2).

When questioned about the body that they would like to have, most women (91.6\%) were dissatisfied and wanted a body different from the one they thought they had (Table 1). Most women wanted a BMI, on average, $9.01 \mathrm{Kg} / \mathrm{m}^{2}( \pm 5.25)$ lower. However, approximately one-third of them wished to increase the body BMl, on average, by $6.43 \mathrm{Kg} / \mathrm{m}^{2}$. A total of $26.0 \%$ of the women who wished to increase their BMI had already excess weight. 
Table 1. Socioeconomic and demographic characteristics, nutritional status and body image of the female inmate population in a closed system (N=107). Natal (RN), Brazil, 2015.

\begin{tabular}{|c|c|c|c|}
\hline \multirow{2}{*}{ Variables } & \multicolumn{2}{|c|}{ Prevalence } & \multirow{2}{*}{$\mathrm{Cl}(95 \%)$} \\
\hline & $\mathrm{N}$ & $\%$ & \\
\hline \multicolumn{4}{|l|}{ Age (years) $(n=106)$} \\
\hline$<30$ & 46 & 43.4 & $33.8-53.4$ \\
\hline $30-49$ & 55 & 51.9 & $42.0-61.7$ \\
\hline$\geq 50$ & 5 & 4.7 & $1.5-10.7$ \\
\hline \multicolumn{4}{|l|}{ Schooling $(n=72)$} \\
\hline Knowing how to read and write/ Basic Education & 47 & 65.3 & $53.1-76.1$ \\
\hline Secondary/Higher Education & 23 & 31.9 & $21.4-44.0$ \\
\hline Post-graduation & 2 & 2.8 & $0.3-9.70$ \\
\hline \multicolumn{4}{|l|}{ Per capita family income $(n=44)$} \\
\hline$<0.25 \mathrm{MW}$ & 30 & 68.2 & $52.4-81.4$ \\
\hline $0.25-0.50 \mathrm{MW}$ & 8 & 18.2 & $8.2-32.7$ \\
\hline$>0.50 \mathrm{MW}$ & 6 & 13.6 & $5.2-27.4$ \\
\hline \multicolumn{4}{|l|}{ Marital Status $(n=107)$} \\
\hline Single/separated/widowed & 73 & 68.2 & $58.5-76.9$ \\
\hline Married/living with a partner & 34 & 31.8 & $23.1-41.5$ \\
\hline \multicolumn{4}{|l|}{ Time of imprisonment $(n=91)$} \\
\hline$<12$ months & 33 & 36.3 & $26.4-47.0$ \\
\hline $12-24$ months & 34 & 37.4 & $27.4-48.1$ \\
\hline$>24$ months & 24 & 26.4 & $17.7-36.7$ \\
\hline \multicolumn{4}{|l|}{ Frequency of visits ( $n=95$ ) } \\
\hline Weekly & 19 & 20.0 & $12.5-29.5$ \\
\hline Fortnightly & 14 & 14.7 & $8.3-23.5$ \\
\hline Monthly & 13 & 13.7 & $7.5-22.3$ \\
\hline Sporadically & 7 & 7.4 & 3.0-14.6 \\
\hline None & 42 & 44.2 & $34.0-54.8$ \\
\hline \multicolumn{4}{|l|}{ Have children $(n=106)$} \\
\hline No & 16 & 15.1 & $8.9-23.4$ \\
\hline Yes & 90 & 84.9 & 76.6-91.1 \\
\hline \multicolumn{4}{|l|}{ Nutritional status ${ }^{*}(n=90)$} \\
\hline Eutrophy & 32 & 35.6 & $25.7-46.3$ \\
\hline Overweight & 33 & 36.7 & $26.8-47.5$ \\
\hline Obesity & 25 & 27.8 & $18.9-38.2$ \\
\hline \multicolumn{4}{|l|}{ Body image distortion $(n=90)$} \\
\hline Absent & 15 & 16.7 & $9.6-26.0$ \\
\hline Present & 75 & 83.3 & $74.0-90.0$ \\
\hline Overestimation of the body & 62 & 82.7 & $72.2-90.4$ \\
\hline Underestimation of the body & 13 & 17.3 & $9.6-27.8$ \\
\hline \multicolumn{4}{|l|}{ Satisfaction with Body Image $(n=107)$} \\
\hline Satisfied & 9 & 8.4 & 3.9-15.4 \\
\hline Dissatisfied & 98 & 91.6 & $84.6-96.1$ \\
\hline \multicolumn{4}{|l|}{ Desired body size $(n=107)$} \\
\hline Increase & 35 & 32.7 & $24.0-42.5$ \\
\hline Reduce & 63 & 58.9 & $49.0-68.3$ \\
\hline Maintain & 9 & 8.4 & 3.9-15.4 \\
\hline
\end{tabular}

Note: " Eutrophy: BMl between 18.5 to $24.9 \mathrm{Kg} / \mathrm{m}^{2}$; Overweight: BMI from 25.0 to $29.9 \mathrm{Kg} / \mathrm{m}^{2}$; Obesity: BMI from $30.0 \mathrm{Kg} / \mathrm{m}^{2}$. MW: Minimum Wage in 2015 (R\$ 788.00); N: Total number of inmates; n: Number of respondent inmates. 


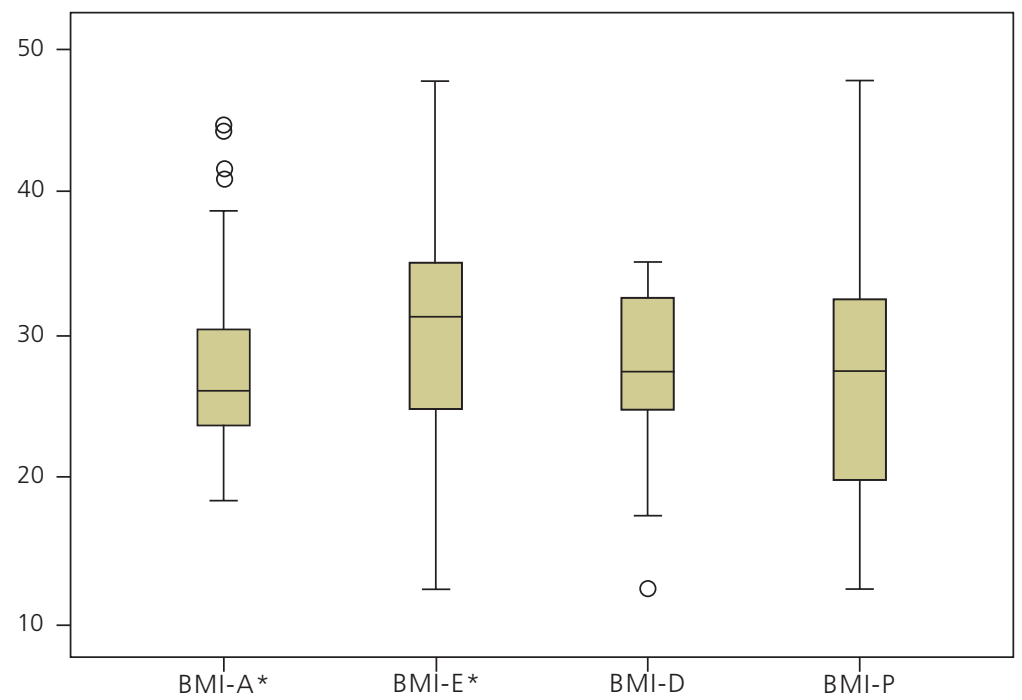

Figure 1. Medians of the different Body Mass Indexes (BMI) evaluated in female prison population in a closed regime $(n=107)$. Natal (RN), Brazil, 2015.

Note: ${ }^{*}$ There was a statistically significant difference between the median values of BMI-A and BMI-E according to the Wilcoxon test $(<0.0001)$. BMI-A: current BMI measured by Anthropometry; BMI-E: Current BMI Estimated by SSF; BMI-D: Desired BMI estimated by SSF; BMI-P: BMI Prior to seclusion, estimated by SSF.

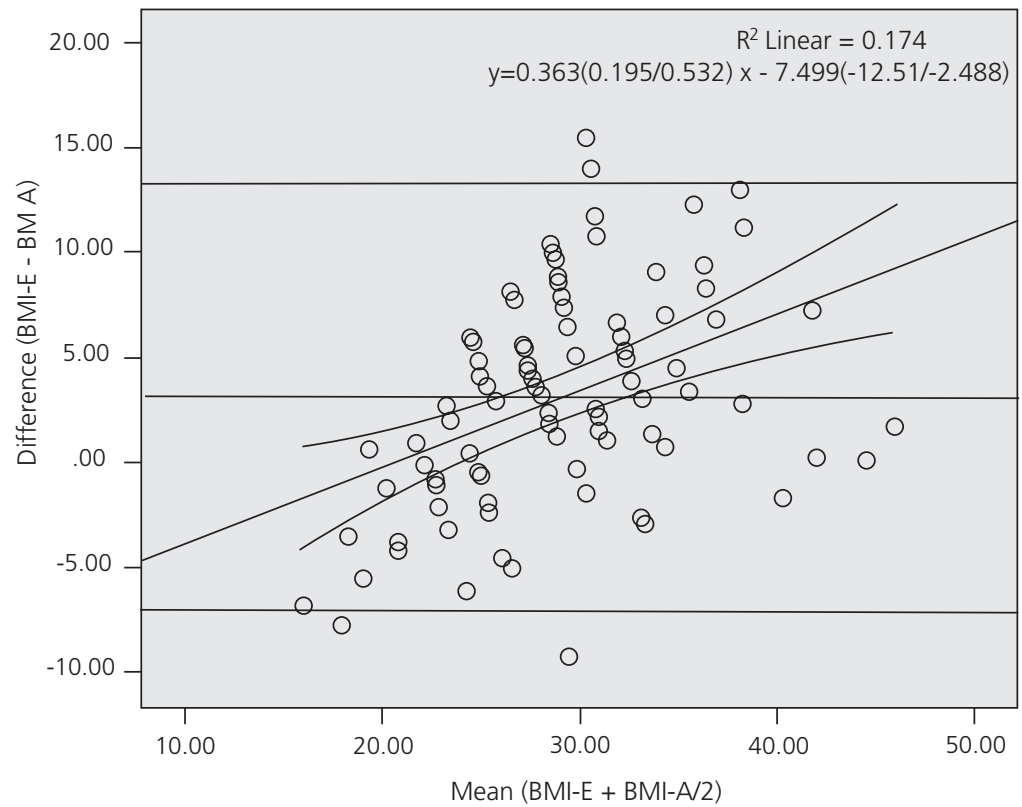

Figure 2. Bland and Altman plots showing the mean difference and the $95 \%$ Confidence limits for different Body Mass Indexes (BMI), with linear regression, evaluated in the female prison population in a closed regime ( $n=107)$. Natal (RN), Brazil, 2015.

Note: BMI-E: Current BMI Estimated by a scale of Figure Silhouettes; BMI-A: current BMI obtained by Anthropometry.

The prevalence of BIDiss did not differ regarding sociodemographic characteristics and nutritional status of the participants. Moreover, BIDiss was not associated with the time of imprisonment ( $\mathrm{PR}=1.06 ; 95 \% \mathrm{Cl}: 0.94-1.19)$ or with the presence of BIDist (PR=1.00; 95\% Cl:0.69-1.45) (Table 2). 
Table 2. Prevalence (\%) and Prevalence Ratios (PR) of Body Image distortion and dissatisfaction according to the characteristics of the female prison population in a closed regime $(n=107)$. Natal (RN), Brazil, 2015.

\begin{tabular}{|c|c|c|c|c|c|c|}
\hline \multirow{3}{*}{ Variables and categories } & \multicolumn{6}{|c|}{ Outcomes } \\
\hline & \multicolumn{3}{|c|}{ Distortion } & \multicolumn{3}{|c|}{ Dissatisfaction } \\
\hline & $\mathrm{N}$ & $\%$ & PR $(95 \% \mathrm{Cl})$ & $\mathrm{N}$ & $\%$ & PR $(95 \% \mathrm{Cl})$ \\
\hline \multicolumn{7}{|l|}{ Age (years) $(n=106)$} \\
\hline$<30$ & 29 & 74.4 & $0.82(0.67-1.01)$ & 42 & 91.3 & $1.00(0.89-1.12)$ \\
\hline$\geq 30$ & 46 & 90.2 & 1.00 & 55 & 91.7 & 1.00 \\
\hline \multicolumn{7}{|l|}{ Schooling $(n=72)$} \\
\hline Secondary/ Higher Education & 18 & 85.7 & 1.00 & 22 & 95.7 & 1.00 \\
\hline Knowing how to read and write/Elementary Education & 27 & 73.0 & $0.85(0.66-1.11)$ & 42 & 89.4 & $0.93(0.82-1.07)$ \\
\hline \multicolumn{7}{|l|}{ Marital Status $(n=107)$} \\
\hline Single/separated/widowed & 52 & 85.2 & $1.08(0.87-1.33)$ & 66 & 90.4 & $0.96(0.86-1.08)$ \\
\hline Married/living with a partner & 23 & 79.3 & 1.00 & 32 & 94.1 & 1.00 \\
\hline \multicolumn{7}{|l|}{ Time of imprisonment (months) $(n=91)$} \\
\hline$\leq 18$ months & 32 & 78.0 & 1.00 & 44 & 89.8 & 1.00 \\
\hline$\geq 19$ months & 30 & 90.9 & $1.17(0.96-1.42)$ & 38 & 95.0 & $1.06(0.94-1.19)$ \\
\hline \multicolumn{7}{|l|}{ Frequency of visits ( $n=95)$} \\
\hline Not regularly & 35 & 87.5 & $1.06(0.88-1.28)$ & 44 & 89.8 & $0.98(0.86-1.12)$ \\
\hline Regularly & 33 & 82.5 & 1.00 & 42 & 91.3 & 1.00 \\
\hline \multicolumn{7}{|l|}{ Have children $(n=106)$} \\
\hline Yes & 65 & 86.7 & 1.00 & 82 & 91.1 & 1.00 \\
\hline No & 9 & 64.3 & $0.74(0.50-1.11)$ & 15 & 93.8 & $1.03(0.89-1.19)$ \\
\hline \multicolumn{7}{|l|}{ Nutritional status ${ }^{*}(n=90)$} \\
\hline Eutrophy & 25 & 78.1 & 1.00 & 30 & 93.8 & 1.00 \\
\hline Excess weight & 50 & 86.2 & $1.10(0.89-1.36)$ & 54 & 93.1 & $0.99(0.89-1.11)$ \\
\hline \multicolumn{7}{|l|}{ Body image distortion $(n=90)$} \\
\hline Present & - & - & - & 70 & 93.3 & $1.00(0.86-1.16)$ \\
\hline Absent & - & - & - & 14 & 93.3 & 1.00 \\
\hline \multicolumn{7}{|l|}{ Body image dissatisfaction $(n=98)$} \\
\hline Present & 70 & 83.3 & $1.00(0.69-1.45)$ & - & - & - \\
\hline Absent & 5 & 83.3 & 1.00 & - & - & - \\
\hline
\end{tabular}

Note: *Eutrophy: BMI between 18.5 to $24.9 \mathrm{Kg} / \mathrm{m}^{2}$; Excess weight: BMl from $25.0 \mathrm{Kg} / \mathrm{m}^{2}$.

$\mathrm{N}$ : Total number of inmates; $\mathrm{n}$ : Number of respondent inmates.

\section{DISCUSSION}

Body Image dissatisfaction and distortion in female prisoners is a very complex matter, going beyond the desire of a beautiful and slim body. This study is pioneering on $\mathrm{BI}$ in a population of imprisoned women in a developing country, demonstrating that almost all of these inmates were dissatisfied with their body image, and one third wanted to increase their body size, including overweight inmates. Body size overestimation was present in almost all women, indicating impaired proprioception in prison environment.

BIDist prevalence evidenced in our study is similar to that reported for young inmates in Australia, although $47.9 \%$ were overweight or obese, and only $24.1 \%$ viewed themselves as above 
weight [12]. In such study [12], 20.4\% perceived themselves with weight below the appropriate, while only $1.0 \%$ were in fact underweight. It is clear, therefore, that both overestimation and underestimation of the $\mathrm{BI}$ may be present among imprisoned individuals.

In this study, the SSF figures identified by women as representing them before imprisonment were, in most cases, smaller bodies than those identified to represent their current body, revealing their perception of weight gain during incarceration. Weight gain was also high in other studies with inmates $[11,12,15,16]$, being more prevalent in women $[16,17]$.

This phenomenon may be related to inadequate diet with low consumption of healthy foods and high consumption of industrialized food, sedentary life style, without working programs or recreational and physical activities, depression or even drug abstinence, and the use of atypical antipsychotic medications $[6,9-11,15,16,18]$.

Damages brought on by continued weight gain and overweight in the prison environment increase the risk for CNCD. Since weight gain occurs gradually in an environment where all people gain weight together and have little contact with others outside the prison, the inmates loses their standards of normality and BI distortion emerges. This is worsened by the fact that in prisons there no scales and anthropometers available for periodic assessment of BMI, and so these women are not sure which body size would be compatible with the nutritional status classified as "overweight or obesity" and could pose a risk of CNDC. Thus, with a distorted BI perception (which in this context of life is linked to the loss of notion about which body size is undesirable) the self-care process is impaired, enabling the aggravation of their nutritional status and the onset of health problems due to excessive weight gain.

The underestimation of $\mathrm{BI}$ occurs both in people living in society [19] and those deprived of their freedom, as observed in this and in other studies [12]. The overestimation of body size is also very frequent in women, regardless of their life context $[1,4,20]$. A Brazilian study with female students revealed a high imprecision in the perception of body size, confirmed by an $81.3 \%$ overestimation [20].

One aspect that could encourage BIDist in prison is the absence of a parameter for body evaluation, since mirrors are prohibited in the detention cells. Thus, they adopt the body of their imprisoned colleagues (who are mostly overweight) as a parameter for comparison. In addition, in this study, the common sense expressed during the interviews, of not having a healthy lifestyle within the prison, may also have influenced the choice of a silhouette that is not representative of a body considered adequate (eutrophy). BIDist may also be related to the use of illicit and psychotropic drugs. Some medications may favor a gradual weight gain [16] without the inmate noticing, resulting in BIDist.

A BIDiss was reported by almost all the participants, and the most of them wanted to have a smaller BMI value. However, about 1/3 desired a larger figure, that is, many wished to be even more corpulent even while having excess weight, showing that the BIDiss issue in prison is very complex, going beyond wanting a beautiful and slim body. Possibly, this behavior is coupled to the desire for a more robust body that intimidates and provides protection against violence and abuse in prisons [21]. In addition, a large body is popularly associated with a "strong" body and less susceptible to diseases. Transsexuality and homosexuality, common among inmates [22], could also result in a desire for greater corpulence. Also, the fact that "becoming a man" inside a female prison can ensure inmates power and privileges socially attributed to men, such as the legitimate use of force [23]. 
Studies with free-living women agree with results presented here, revealing that not always the ideal of thinner body type is the desire of women [20,24]. In Brazil, 79.1\% of the female university students had BIDiss, and $18.9 \%$ of them also mentioned the wanting a larger body [20]. BIDiss was positively associated with the BIDist, with the real BMI, criticism from family and friends, overall dissatisfaction with life, internalization of media messages and TV exposure $[1,5,20]$. It was also shown that the greater the personal and family income and education, the lower the BIDiss of women $[1,25]$. Some of these factors are not present in prison or are limited, such as TV exposure. This may have possibly been the reason why the BIDiss was not associated with BI distortion in this study.

In this study, the BIDist and BIDiss associations with the time of imprisonment were not proven, possibly due to the homogeneity of the sample regarding this variable, to the self-report character of this variable, or to the insufficient incarceration time to affect BI. It was also expected to be associated with receiving visitors, since most inmates were not visited for body referencing or for comment on changes in their physical appearance. However, that incarceration time may have not been long enough to have such an effect on the participants.

Studies corroborate the lack of association between BIDiss and nutritional status [26], as well as BIDiss [27]. Other researchers, however, showed that women have BIDiss notably due to excess weight $[20,27]$, showing a lack of consensus on the subject.

Another important point that can influence on $\mathrm{Bl}$ is the expression of femininity in the prison system, which is continually suppressed. The prison environment itself is male and masculinizing in practice, which makes femininity even more invisible [28]. The use of masculine uniforms is mandatory, and the use of nail polish, props and other beauty items is prohibited, causing additional suffering for those who want to cultivate their femininity as a form of identity.

In and through the body is established institutional control of women in confinement [28]. Their daily life is marked by adversity and the administrative measures imposed on them seek control over their bodies, behaviors and subjective states [8,29,30], and are imposed a series of stigmas and also self-stigmatize. Most women are not visited regularly, and the abandonment by the family is frequent. Some, because they feel unworthy, ask family members not to visit them, which contributes even more to the "death" of their individuality [29].

This whole situation is possibly entwined with the self-esteem of these women and how they perceive their bodies. For Melo et al. [29], even control practices on the part of the penitentiary agents, act directly over the bodies and in the subjectivity of these women, who are often subjected to deprivation of visiting rights and from receiving objects and food, and to delays in the provision of information on their process, or suspension of social conviviality in isolation cells.

Some limitations inherent to this study should be considered, such as the incompleteness of some responses from the questionnaire due to disinterest, embarrassment, or ignorance; the limited time for data collection given the schedule imposed by the direction of the prison; and the impossibility of interviewing the inmates in a private location. Moreover, the life and current history on abuse and violence, the use of licit and illicit drugs, use of medications, presence of psychiatric problems, eating disorders, violence, or even the emotional fragility that permeates the violent and exclusionary prison environment were not assessed.

The referred information of time of imprisonment had to be used for the analyses, since it was not possible to obtain this data reliably from the direction of the prison. Many had already served time in detention regimes or had been detained in other moments of life in a closed system 
and may not have counted correctly this period in their response. Thus, the association between the prevalence of BIDist and BIDiss with time of incarceration may have been weakened, masking the real effect of the arsenal of suffering caused by the environment.

Despite these limitations, the originality of this study in the national and international scenario brings to light the importance of attention to health issues that were previously ignored among incarcerated women, who are already living in a situation of vulnerability in relation to CNCD and other diseases. Thus, meets the current need to strengthen health promotion in prison settings [30], which may result in promising outcomes for individual, community and public health gain. Also reinforces the emphasis of comprehensive, multidisciplinary and transdisciplinary health promotion actions aimed at this population group to reduce the health inequalities in the prison system.

\section{CONCLUSION}

Female prisoners presented a high prevalence of BIDist and BIDiss, which increases their situation of vulnerability in relation to CNCD and other diseases and indicate the need for these aspects to be included in the health promotion actions in the prison system.

\section{CONTRIBUTORS}

All authors performed the data analysis and interpretation of the results, prepared, reviewed and approved the final version of the manuscript. APDI BARBOSA conducted the literature review and participated in data collection in the field. UV BAGNI collaborated in all stages of the study, including design and planning; performance and coordination of data collection in the field.

\section{REFERE NCES}

1. Ábrahám I, Jambrik M, John B, Németh AR, Franczia N, Csenki L. Body image and body image distortion. Orv Hetil. 2017;158(19):723-30.

2. Laus MF, Kakeshita IS, Costa TMB, Ferreira MEC, Fortes LS, Almeida SS. Body image in Brazil: Recent advances in the state of knowledge and methodological issues. Rev Saúde Pública. 2014;48(2):331-46.

3. Mauerberg-de-Castro E, Tavares CP, Paula Al, Crozara GB, Campbel DF. Using psychophysical tools to quantify body image perception: A tutorial. Mot Rev Educ Física. 2015;21(4):329-43.

4. Ribeiro RG, Kruse MHL. The woman body in review: The imperative of beauty. Texto Context Enferm. 2014;23(1):101-8.

5. Heiman T, Olenik-Shemesh D. Perceived body appearance and eating habits: The voice of young and adult students attending higher education. Int J Environ Res Public Health. 2019;16(3):E451. http://dx.doi. org/10.3390/ijerph16030451

6. Andrade ALCC, Barbosa APDI, Bagni UV. Imagem corporal no cárcere: percepções de mulheres privadas de liberdade. Demetra. 2018;13(2):381-39.

7. Figueiró RA, Dimenstein M. Castigo, gestão do risco e da miséria: novos discursos da prisão na contemporaneidade. Estud Psicol (Natal). 2016;21(2):192-203.

8. Verdi M, Matias MCS, Garcia Júnior CAS. Acolhimento e humanização nas práticas de gestão e atenção à saúde de pessoas privadas de liberdade: Curso de Atenção à Saúde das Pessoas Privadas de Liberdade. Florianópolis: Universidade Federal de Santa Catarina; 2015.

9. Audi CAF, Santiago SM, Andrade MGG, Francisco PMSB. Inquérito sobre condições de saúde de mulheres encarceradas. Saúde Debate. 2016;40(109):112-24. 
10. Soares-Filho MM, Bueno PMMG. Demografia, vulnerabilidades e direito à saúde da população prisional brasileira. Ciênc Saúde Coletiva. 2016;21(7):1999-2010.

11. Santos MV, Alves VH, Pereira AV, Rodrigues DP, Marchiori GRS, Guerra JVV. A saúde física de mulheres privadas de liberdade em uma penitenciária do estado do Rio de Janeiro. Esc Anna Nery. 2017;21(2):e20170033. http://dx.doi.org/10.5935/1414-8145.20170033

12. Haysom L, Indig D, Moore E, Hardy LL, Dolder PA. Prevalence and perceptions of overweight and obesity in Aboriginal and non-Aboriginal young people in custody. Med J Aust. 2013;199(4):266-70.

13. Barros RCA. Mulheres no cárcere: um estudo sobre os símbolos e imagens produzidos a partir de suas identidades corporais [Dissertação]. Universidade Federal de Mato Grosso; 2016.

14. Kakeshita IS, Silva AIP, Zanatta DP, Almeida SP. Construção e fidedignidade teste-reteste de escalas de silhuetas brasileiras para adultos e crianças. Psicol Teor Pesq. 2009;25(2):263-70.

15. Bailey ZD, Williams DR, Kawachi I, Okechukwu CA. Incarceration and adult weight gain in the National Survey of American Life (NSAL). Prev Med. 2015;81:380-6.

16. Gates ML, Bradford RK. The impact of incarceration on obesity: Are prisoners with chronic diseases becoming overweight and obese during their confinement? J Obes. 2015;(1):1-7.

17. Khodabakhshifard A, Safarian M, Rostami S, Zamani S, Mazidi M, Arabi M, et al. Evaluation of the nutritional status using the anthropometric indices and dietary intakes in the central prison of Mashhad. J Biol Today's World. 2014;3(12):266-70.

18. Canazaro D, Argimon II L. Características, sintomas depressivos e fatores associados em mulheres encarceradas no Estado do Rio Grande do Sul, Brasil. Cad Saúde Pública. 2010;26(7):1323-33.

19. Park B, Cho HN, Choi E, Seo DH, Kim S, Park YR, et al. Self-perceptions of body weight status according to age-groups among Korean women: A nationwide population-based survey. PLOS One. 2019;14(1):e0210486. http://dx.doi.org/10.1371/journal.pone.0210486

20. Jaeger MB, Câmara SG. Media and life dissatisfaction as predictors of body dissatisfaction. Paideia. 2015;25(61):183-90.

21. Rodrigues VI, Hechler AD, Henrich GKL. Gênero e privação de liberdade: as condições de vida das mulheres na prisão. Rev Iniciação Cien ULBRA. 2012;(10):83-9.

22. Nicolau AIO, Ribeiro SG, Lessa PRA. Retrato da realidade socioeconômica e sexual de mulheres presidiárias. Acta Paul Enferm. 2012;25(3):386-92.

23. Barcinski M. Expressões da homossexualidade feminina no encarceramento: o significado de se "transformar em homem" na prisão. Psico-USF. 2012;17(3):437-46.

24. Tuoyire DA, Kumi-Kyereme A, Doku DT, Amo-Adjei J. Perceived ideal body size of Ghanaian women: "Not too skinny, but not too fat". Women Health. 2018;58(5):583-97.

25. Skopinski F, Resende TL, Schneider RH. Imagem corporal, humor e qualidade de vida. Rev Bras Geriatr Gerontol. 2015;18(1):95-105.

26. Raso V, Garber CE, Mancini RB, Matsudo SMM. Body image in a representative sample of overweight, obese and normal weight active older women living in the community: Associations with body composition, physical fitness and function. Med Express. 2016;3(4):M160402. http://dx.doi.org/10.5935/ MedicalExpress.2016.04.02

27. Jackson KL, Janssen I, Appelhans BM, Kazlauskaite R, Karavolos K, Dugan SA, et al. Body image satisfaction and depression in midlife women: The Study of Women's Health Across the Nation (SWAN). Arch Womens Ment Health 2014;17(3):177-87.

28. Barcinski M, Cúnico SD. Os efeitos (in)visibilizadores do cárcere: as contradições do sistema prisional. Psicologia. 2014;28(2):63-70.

29. Melo JG, Alves L, Cavalcante J. Do lado de dentro e do lado de fora: justiça e criminalidade a partir de perspectivas de mulheres em situação de prisão e na condição de visitantes. Vivência Rev Antropol. 2015;1(46):113-30.

30. Woodall J, Dixey R. Advancing the health-promoting prison: A call for global action. Glob Health Promot. 2017;24(1):58-61. 